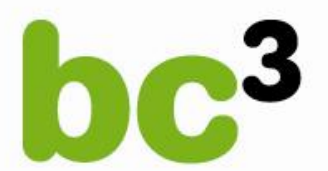

BASQUE CENTRE

FOR CLIMATE CHANGE

Klima Aldaketa Ikergai

\title{
Environmental Fiscal Reform and \\ Unemployment in Spain
}

Anil Markandya, Mikel González-Eguino and Marta Escapa

April 2012

BC3 WORKING PAPER SERIES 
The Basque Centre for Climate Change (BC3) is a Research Centre based in the Basque Country, which aims at contributing to long-term research on the causes and consequences of Climate Change in order to foster the creation of knowledge in this multidisciplinary science.

The BC3 promotes a highly-qualified team of researchers with the primary objective of achieving excellence in research, training and dissemination. The Scientific Plan of BC3 is led by the Scientific Director, Prof. Anil Markandya.

The core research avenues are:

- Adaptation to and the impacts of climate change

- Measures to mitigate the amount of climate change experienced

- International Dimensions of Climate Policy

- Developing and supporting research that informs climate policy in the Basque Country

See www.bc3research.org for further details.

The BC3 Working Paper Series is available on the internet at

http://www.bc3research.org/lits_publications.html

Enquiries (Regarding the BC3 Working Paper Series):

Roger Fouquet

Email: roger.fouquet@bc3research.org

www.bc3research.org

The opinions expressed in this working paper do not necessarily reflect the position of Basque Centre for Climate Change (BC3) as a whole.

Note: If printed, please remember to print on both sides. Also, perhaps try two pages on one side. 


\title{
Environmental fiscal reform and unemployment in Spain
}

\author{
Anil Markandya ${ }^{1}$, Mikel González-Eguino ${ }^{1}$ and Marta Escapa ${ }^{2}$
}

The theoretical literature relevant to the relationship between environmental taxation and employment creation is centred on the suggestion by Pearce (1991) that environmental taxation could lead to a "double dividend". In this paper we review the literature on the employment double dividend for Spain and add to it with some new analysis of our own that fills some important gaps in the literature.

Keywords: Environmental fiscal reform, double dividend hypothesis, unemployment, Spain JEL Classification: H2, Q5

Cite as: Markandya A., González-Eguino, M. Escapa, E. (2012). Environmental fiscal reform and unemployment in Spain, BC3 Working Paper Series 2012-04. Basque Centre for Climate Change (BC3). Bilbao, Spain.

\footnotetext{
${ }^{1}$ Basque Centre for Climate Change (BC3), Alameda Urquijo, 4, 4a 48008 Bilbao, Spain

${ }^{2}$ Dept. Fund. Análisis Económico I and Instituto de Economía Pública, University of the Basque Country, UPV/EHU, Spain
} 


\section{Introduction}

The theoretical literature relevant to the relationship between environmental taxation and employment creation is centred on the suggestion by Pearce (1991) that environmental taxation could lead to a "double dividend". The idea behind this suggestion is that environmental taxes not only produce improvements in the environment but they also generate substantial amounts of government revenue. This new revenue allows governments to reduce the rates of other taxes in the economy while maintaining a constant level of total revenue and expenditure. As these other taxes are generally 'distortionary' (i.e. they interfere with the efficient functioning of markets), the reduction in their rates can be seen as improving efficiency and thus producing a second benefit from the adoption of environmental taxes.

In this paper we review the literature on the employment double dividend for Spain and add to it with some new analysis of our own that fills some important gaps in the literature. The paper is structured as follows. Section 2 provides a theoretical discussion of the double dividend, analysing when we can expect to realise employment gains from a shift towards environmental taxes and when such gains are unlikely. Section 3 looks at the evidence for the double dividend for Spain and includes the results of a model we have developed for that country. Section 4 concludes with some reflections on where further research is needed and where the case for action is clear.

\section{The Theory of How and Why an Employment Dividend May Exist ${ }^{2}$}

Environmental taxes are different to other types of taxes because their primary purpose is to reduce damage to the environment by increasing the costs of harmful actions. The size of the taxes

\footnotetext{
${ }^{2}$ An extended version of the analysis presented in section 2 can be found in Markandya (2011) and Heady et al. (2000).
} 
(Piguovian taxes) should equal the monetary value of the marginal environmental damage that the actions cause. If the revenue from such taxes were sufficiently large to fund all government expenditures, then existing distortionary taxes could be completely removed and the economy would be undistorted by either taxation or environmental externalities. However, it is difficult for Pigouvian taxes to raise the necessary level of revenue to fund all government expenditures and environmental taxes are used to reduce rather than to replace other taxes. This means the tax-interaction-effect (between environmental taxes and other taxes) has to be considered, and it is this interaction that causes the analysis to be so complicated.

In the case with Involuntary Unemployment ${ }^{3}$, one way to create additional employment is by reducing taxation of workers in order to increase the demand for labour. However, since a reduction in employment taxes is accompanied by an increase in other taxes, the latter will increase the prices of goods and thus reduce the real wage. This in turn will cause workers to demand wage increases cancelling the benefit of the employment tax cut. In these circumstances there are two possible ways of replacing existing taxes by environmental taxes to achieve this effect:

(i) Shifting the tax burden from workers to other groups: when some consumers are not workers (people on state benefits, living on capital income or from other countries), a shift from payroll taxes to environmental taxes could increase employment.

(ii) Improving the efficiency of the tax system: in many countries (particularly Western European countries) labour is taxed more heavily than other factors and a shift away from the taxation of labour to the taxation of other factors can be expected to reduce production costs.

\footnotetext{
${ }^{3}$ In economic terms unemployment is caused by the wage being higher than its market clearing value. This leads to a situation where the demand for labour is less than its supply, and the result is involuntary unemployment. In the case voluntary unemployment, the emphasis in the double dividend literature moves away from employment creation and towards the general efficient functioning of markets. However, there is very little gain in individual welfare in moving somebody from voluntary unemployment into employment, in contrast to the very substantial gains in moving somebody from involuntary unemployment into employment.
} 
In addition to the points noted above, the conditions that prevail in the labour market are also relevant. In particular, two that could be of some importance, especially in the Spanish context, are those related to (i) the mix of skilled and unskilled labour and (ii) the extent of an informal labour market (that is not taxed) alongside the formal one that is taxed.

In the context of environmental tax reform, we might have expected a higher employment dividend if the measures target are the lower skilled workers instead of the more skilled group given that demand and supply are more elastic for the first group. However, CGE models that have looked at this question do not come up with such a result. Bosello and Carraro (2001) find that employment effects are larger when taxes are reduced for all categories of labour, whereas Fæn et al, (2009) find that the most successful reforms are those where the tax reductions are concentrated on skilled types of labour. It is not hard to see why the results in the CGE models may be different from the basic intuition. They depend not only on the direct demand and supply elasticities of the two groups but also on the degree to which labour with different levels of skill can be substituted for each other (i.e. the elasticity of substitution between skilled and unskilled labour ${ }^{4}$ ), the substitutability between energy and different kinds of labour and, most importantly, the extent to which supply of labour rises under collective bargaining in each group as the real wage increases (i.e. the elasticity of the wage curve). This last factor results in less employment benefits from tax reductions to unskilled workers if their real wages are more likely to rise when demand increases than they are for skilled workers. These are all empirical questions.

As far as the informal sector is concerned one needs to model the linkages between the two labour markets. One way of doing that is to assume expected wages in the two sectors are equal, so an informal sector worker earns an amount equal to the wages times the probability of employment in the

\footnotetext{
${ }^{4}$ With a high degree of substitutability between the two kinds of labour a rise in the real wage for one would result in a large switch in employment of the other. In this case the overall effect of a tax reduction for one group would be to increase employment (reduce unemployment) relatively evenly across both groups.
} 
formal sector. The idea is taken from Harris and Todaro (1970) who used it to explain rural-urban migration and this same approach has been developed by Rutherford and Light (2002) in a CGE model for Colombia involving the informal sector.

Two further policy issues relevant to the double dividend merit consideration. First, it is important to take into account capital mobility and the need for international co-operation in setting environmental taxes. If capital is mobile and taxes are imposed in one country in isolation it could suffer from substantial outward capital movement. Second, we may have a negative distributional impact of a tax reform if the dividends generated come from shifting the tax burden to non-workers like pensioners or unemployed persons ${ }^{5}$.

\section{Empirical Evidence for the Double Dividend in Spain}

In this section we will examine the potential for the employment double dividend in Spain. Two additional features that may play an important role in the emergence and size of the double dividend are considered: the role of skilled and unskilled labour and the role of an informal labour market where labour is untaxed.

\subsection{Background}

Spain has traditionally had a high level of unemployment relative to its European neighbours and other trading partners as well as a large informal labour market. Regarding unemployment the current

\footnotetext{
5 Most of the empirical models work with a representative household. A model with different categories of households should be used to test distributional consequences of the tax reform.
} 
level of around 20\%, while high, is in fact similar to that experienced in 1995 and the low levels of 1998-2006 were exceptional for the country.

The other important feature of the labor market in Spain is the informal or shadow economy. A comprehensive survey regarding definitions and estimation procedures of the shadow economy can be found in Schneider and Enste (2000). In Schneider (2011) and Buehn and Schneider (2011) a review of the main empirical studies that measure the size of the shadow economy is provided. The conclusion from these studies is that the main driving forces of the shadow economy are tax and social security contribution burdens, 'tax morale' (or the intrinsic motivation of individuals to pay taxes) and the intensity of state regulations.

Arrazola et al. (2010) estimate the size of the shadow economy for Spain following different methodologies. They conclude that for the period 2005-08 the shadow economy represented $21.5 \%$ of GDP, with a loss of revenue for the government of $7 \%$ of GDP. This shadow economy engages 4.3 million shadow jobs. These results are in line with those collected by Buehn and Schneider (2011), where the average shadow economy in Spain corresponds to 22.5\% of GDP from 1999 to 2007 . To date, however, the CGE models for Spain that look at the double dividend do not address this aspect of the labour market.

\subsection{Previous Studies of Environmental Tax Reform in Spain}

There are two relevant previous studies that estimate the extent of a double dividend specifically for Spain considering its effects on unemployment ${ }^{6}$ : Manresa and Sancho (2005) and Fæn et al. (2009).

\footnotetext{
${ }^{6}$ There are other articles that estimates the impact of CO2 taxes on Spanish economy (for example see González-Eguino 2011 or Labandeira et al 2009).
} 
Both are CGE models that evaluate a carbon tax or a permit scheme for the country, recycled through a range of measures, one of which is a reduction in employment taxes. The models assume equilibrium in all markets except the labour market, where involuntary unemployment is allowed for through a 'wage curve' representing, for each level of employment, a wage that is higher than the reservation wage for workers to supply that amount of labour (Blanchflower and Oswald, 1995, 2005). Both studies rely on the 1990 Spanish Input-Output Table to calibrate the model, which makes the results suspect to changes in the structure of the economy. The main features of both models are summarised in Table 1.

The Manresa and Sancho study looked at two taxes: a 10 percent tax on all energy products and a 15 percent tax on petrol and other petroleum products. These are not of course taxes on carbon across the economy (non-energy activities that generate carbon emissions are not covered) but they can be converted into an implied tax on carbon ${ }^{7}$. We have done that, using the 1990 data on fuels used and converted the implied charges into a tax per ton of $\mathrm{CO} 2$ in 2010 dollars. The rates turn out to be surprisingly high: the 10 percent energy tax implies a CO2 tax of around US\$22.0 and the combination of the energy and petroleum taxes amount to a tax of nearly US\$32 per ton of CO2. The study then looked at the resulting reductions in unemployment, emissions and the changes in welfare. It did this for two 'elasticities' of the wage curve: 0.8 and zero. The higher the elasticity the greater is the increase in the wage when the demand for labour goes up and the less is the decrease in employment ${ }^{8}$.

\footnotetext{
${ }^{7}$ The calculation is made using the 1990 supply and use tables for Spain and assuming other taxes on fossil of about 40 percent. This can only be an approximation as we need detailed tax information for these products to make an accurate estimate. Unfortunately this was not available.

${ }^{8}$ The 'elasticity' is defined differently in the Manresa and Sancho paper from the way and other more recent authors define it. Essentially they define the wage curve in terms of employment and take the elasticity as the inverse of the value that is used in the later papers. To be comparable across studies we estimated an equivalent elasticity assuming a benchmark level of unemployment of $10 \%$ and an actual level of $20 \%$. This gives the values reported in Table 1 .
} 
Table 1: Double Dividend from an Energy Tax in Spain

\begin{tabular}{|c|c|c|c|c|c|c|}
\hline & $\begin{array}{c}\text { Tax Rate } \\
\text { US\$2010/ton } \\
\text { CO2 }\end{array}$ & $\begin{array}{l}\text { Recycling Via Lower } \\
\text { Labour Tax }\end{array}$ & $\begin{array}{c}\text { \% Change in } \\
\text { Unemployment }\end{array}$ & $\begin{array}{c}\text { Change in } \\
\text { Employment }\end{array}$ & Emissions & Welfare \\
\hline \multirow{5}{*}{$\begin{array}{c}\text { Manresa } \\
\& \\
\text { Sancho }\end{array}$} & \multirow{2}{*}{22.0} & Wage Elasticity $=0.15$ & -0.63 & n.a. & $-2.82 \%$ & $0.03 \%$ \\
\hline & & Wage Elasticity $=0$ & -2.33 & n.a. & $-1.76 \%$ & $0.66 \%$ \\
\hline & \multirow{3}{*}{31.9} & Wage Elasticity $=0.15$ & -0.65 & n.a. & $-3.46 \%$ & $-0.03 \%$ \\
\hline & & & & & & \\
\hline & & Wage Elasticity $=0$ & -2.43 & n.a. & $-2.31 \%$ & $0.63 \%$ \\
\hline \multirow{4}{*}{ Fæn et al. } & \multirow{4}{*}{24.3} & On All Labour & $-0.09 \%$ & $0.53 \%$ & $-25.00 \%$ & $-0.47 \%$ \\
\hline & & & & & & \\
\hline & & On Unskilled Labour & $0.07 \%$ & $0.48 \%$ & $-25.00 \%$ & $-0.48 \%$ \\
\hline & & On Skilled Labour & $-0.31 \%$ & $0.54 \%$ & $-25.00 \%$ & $-0.47 \%$ \\
\hline
\end{tabular}

Source: Manresa \& Sancho (2002) and own calculations. Fæn, Gomez-Plana and Kverndokk (2009).

Note: Welfare gains are measured in terms of changes in the equivalent variation.

The higher tax rate of US $\$ 31.9$ represents the case where a $15 \%$ tax on petroleum products is included.

The results show a significant reduction in unemployment in all cases but a very large one if the wage curve is infinitely elastic ${ }^{9}$. Hence a change in unemployment of $2.43 \%$ which emerges from the infinite elasticity is on the high side and the fall of $0.63 \%$ is probably on the low side.

The results show a modest additional gain in terms of reduced unemployment if a petroleum tax is added to the overall energy tax; although the additional tax does increase the overall implied carbon tax quite a lot it does not generate much in the way of additional macroeconomic benefits. However, the combined energy and petroleum taxes reduce emissions by 3.46 percent while the energy tax

\footnotetext{
${ }^{9}$ The paper includes two variants of the technology specification: one that assumes fixed coefficients and no substitutability between inputs and the other that allows for such substitution. We only look at the latter as the former is not of much interest as a guide to the medium to long term impacts of a tax change.
} 
alone reduces it by only 2.82 percent. Finally, the model shows very little change in welfare from the tax. It should be noted, however, that the measurement of welfare is flawed to the extent that it does not account for the reduction in emissions of harmful pollutants and for the value of the reduction in $\mathrm{CO} 2$.

The Fæn et al. study focussed on the differences between recycling the revenues from an auction of permits through reduced taxes on skilled labour versus reduced taxes on unskilled labour. They considered a 25 percent reduction in the number of permits issued from the baseline level. The implied price of the permits is around US $\$ 24 /$ ton of $\mathrm{CO} 2^{10}$. The arguments for and against reducing taxes on skilled and unskilled labour were presented earlier. To summarise we cannot say a priori whether one change in taxation is more effective in reducing unemployment than another.

The results of the tax reform in this case are more modest than for the previous study: unemployment falls by only 0.1 percent with the tax on all labour and by 0.3 percent if the tax is on skilled labour. Hence the analysis favours a recycling of the tax via a reduction on employment taxes on skilled labour. The changes in employment, however, are more equal across the three tax recycling schemes, suggesting that the recycling via unskilled labour has a greater supply side effect than that via skilled labour. The model also shows a small loss of welfare in each case but, as in the previous study, this loss does not take account of the gains in welfare (which could be considerable) from the reductions in emissions of local pollutants or $\mathrm{CO}_{2}$.

Thus while both studies show a positive effect from the tax change there are clear differences between them in quantitative terms. Manresa and Sancho estimate a reduction in unemployment of about 0.63 percent with a realistic elasticity for the wage curve, while Fæn et al estimate a reduction of between

${ }^{10}$ Communication from the authors. 
0.1 percent and 0.3 percent. Both models are based on an structure of the economy (1990), which may give misleading results for a tax reform introduced today. They also differ considerably in terms of elasticities of substitution. Manresa and Sancho assume fixed coefficients for energy and a CobbDouglas substitution function for labour and capital. Fæn et al. allow for greater substitution possibilities between energy and capital, so an increase in the price of energy results in more capital being deployed and less of a shift from energy to labour. Finally neither model considers the issues of the informal labour market, something that is particularly important in Spain, which has one of the highest shares of an informal economy in the developed world (20-25 percent). In the next section we show the results obtained with a model where the informal labour sector is considered.

\subsection{A new model of the Spanish economy with an informal labour sector}

\subsubsection{Description of the Model}

A new model has been developed for the Spanish economy that takes into account the informal labor market. The model is described in greater detail in González-Eguino et al (2011). The structure is a familiar one, based on a static Applied General Equilibrium model of the same kind as used by Manresa and Sancho (2002) and Fæn et al. (2009). The main differences from earlier models are the following:

a) There are two kinds of labour: formal and informal, which are imperfect substitutes for each other in production $\sigma_{\mathrm{L}}$ corresponds to the elasticity of substitution between formal and informal labour. As $\sigma_{L} \rightarrow \infty$ formal and informal labor become perfect substitutes.

b) Although total labor endowment is fixed, as is the initial allocation of labor between the formal and informal sectors, there is mobility between two which is modeled through an endogenous parameter $m$ and an equilibrium condition that relates the real-wage differential and unemployment, following Harris and Todaro (1970). The mobility between formal and 
informal market takes place to the point where the real wage for informal employment is equal to expected formal wage (see equation 1). The expected wage in the formal sector is the wage, $w_{F}$, times the formal employment rate (1rma. If ' $u$ ' rises the gap between formal and informal wages widens and more labour moves to the informal sector, lowering wages there until the two are equal again.

Labour supply for the formal and informal sectors is therefore determined by the mobility rate (m) and the unemployment rate (u) as shown in equations (2) and (3).

$$
\begin{aligned}
& L^{F}=L_{0}^{F}(1-u)+L_{0}^{I}(1-\mathrm{m}) \\
& L^{I}=L_{0}^{I} m
\end{aligned}
$$

Where $\mathrm{L}^{\mathrm{F}}$ is the actual amount of formal labor employment, $\mathrm{L}^{\mathrm{I}}$ the actual amount of informal labor employment and $\mathrm{L}_{0}^{\mathrm{F}}$ and $\mathrm{L}_{0}^{\mathrm{I}}$ are the initial allocations of total labor supply to the formal and informal sectors respectively. The level of unemployment in the formal sector is $u$ and the degree of mobility between the informal and formal sectors is $m$. Note that $m$ is an endogenous parameter determined by the Harris-Todaro condition (equation 1).

\subsubsection{Calibrating the Model}

The initial equilibrium data come from the Symmetric Input Output Table (INE 2009a). Energy consumption in physical units for each sector and fossil fuel is estimated from the sectoral energy balance sheets (Eurostat, 2005) and emissions are calculated via the standard coefficients ${ }^{11}$ for coal, oil and gas. The reaction of agents to changes is reflected through elasticities of substitution as given

\footnotetext{
${ }^{11}$ The physical emission coefficients used are the standard used by Eurostat (2005): tonnes of $\mathrm{CO}_{2}$ per Ktoe for coal (4.104), oil (2.851) and gas (2.187).
} 
in Babiker et al. 2001. Based on the cited studies (Arrazola et. al (2010), Buehn and Schneider (2011)) the base case shadow economy is taken as $20 \%$ of the official GDP and the official unemployment rate is set at $20 \%$. It is commonly accepted that there are some economic sectors where the shadow economic activities are more important because the percentage of undeclared work is higher than in others. Therefore, we assume three types of sectors according to their high, medium or low contribution to the shadow economic activity. The selection of sectors under each category and the level of informal labour are based on Hvidtfeldt $(2011)^{12}$.

\subsubsection{The Results}

The simulations looked at $\mathrm{CO}_{2}$ taxes set to reduce emissions by amounts ranging from $5 \%$ to $30 \%$. The revenues obtained from the $\mathrm{CO} 2$ emission permits were "recycled" via (i)) lump sum transfers (LST tax reform), (ii) reducing taxes on labour ( $\mathrm{L}$ tax reform) or (iii) reducing taxes on capital ( $\mathrm{K}$ tax reform). We assume that all these tax reforms are revenue neutral (government revenue is fixed) so welfare impacts can be compared. The main results are as follows:

A. With no mobility between the two labour sectors and with unemployment in the formal sector fixed, all three tax reforms reduce welfare as measured by the equivalent variation. For a $15 \%$ reduction in emissions the fall in welfare is about $0.1 \%$ and there is virtually no difference between the three tax reforms. If, however, we allow for mobility between the sectors and make the elasticity of the wage curve around 0.1 (a typical value, see Blanchflower and Oswald 2005) we find that the three reforms result in major differences in welfare (see Table 2). Whereas the LST and K tax reforms still reduce welfare, the L tax reform increases welfare. Again looking at

\footnotetext{
${ }^{12}$ Hvidtfeldt et al. (2011) use an interview survey to estimate the percentage of undeclared work for different sectors of the Danish economy in 2010. They obtain that $48 \%$ of undeclared work is done in the construction sector, followed by agriculture (47\%), motor vehicle sales and repairs (43\%), manufacturing (36\%), transport and telecommunications (31\%) and hotel and restaurant (30\%).
} 
a $15 \%$ reduction in emissions we find that welfare in cases (i) and (ii) falls by about $0.91 \%$, in case (iii) it now increases by about $2.9 \%$.

Table 2: Welfare impacts ( $\%$ Equivalent Variation) with mobility $\left(\sigma_{L}=5\right)$ and flexible unemployment $(\theta=0.1)$

\begin{tabular}{lrrrrrr}
\hline & \multicolumn{7}{c}{ CO2 Emission reduction (\%) } \\
Alternative Tax Recycling & $5 \%$ & $10 \%$ & $15 \%$ & $20 \%$ & $25 \%$ & $30 \%$ \\
\hline LST & -0.22 & -0.52 & -0.91 & -1.43 & -2.10 & -2.96 \\
TaxK & -0.21 & -0.51 & -0.91 & -1.43 & -2.10 & -2.96 \\
TaxL & 1.05 & 2.02 & 2.89 & 3.65 & 4.27 & 4.72 \\
\hline
\end{tabular}

B. The welfare effects depend strongly on the elasticity of the wage curve and the degree of substitutability between formal and informal labour. The results shown in Table 3, where the lower the wage curve elasticity $(\theta)$ the greater the welfare gains of an L reform. Additionally we find that the higher the elasticity of substitution between formal and informal labour $\left(\sigma_{L}\right)$ the greater is the welfare gain. This arises because the reform raises wages in the formal sector, which moves labour from the informal to the formal sector, increasing its welfare and reducing the deadweight losses arising from a smaller loss of government revenue from the informal sector.

C. As far as unemployment and the shadow economy are concerned the main findings are shown in Table 4. The case considered is a $15 \%$ reduction in the emissions of $\mathrm{CO} 2$ in Spain and the three tax reforms are compared. Table 4 shows a major gain with labour tax recycling in terms of reduced unemployment. The latter falls by $3.5 \%$ with this tax, while it actually rises slightly in the case of a recycling of revenues with a lump sum tax or with a capital tax. The level of CO2 tax required to achieve the $15 \%$ reduction in emissions, however, is quite high - around US\$62 per ton $\mathrm{CO} 2$ emitted. 
Table 3: Welfare impacts ( $\%$ EV) with mobility and flexible unemployment for a $15 \%$ reduction in $\mathrm{CO} 2$ emissions with reduction in labour taxes.

\begin{tabular}{|c|c|c|c|}
\hline & $\theta=\infty$ & $\theta=0.1$ & $\theta=0$ \\
\hline$\sigma_{L}=0$ & -0.09 & 0.21 & 0.46 \\
\hline$\sigma_{L}=5$ & 1.52 & 2.89 & 4.48 \\
\hline$\sigma_{L}=10$ & 4.51 & 4.75 & 7.23 \\
\hline
\end{tabular}

Note: $\theta$ is the elasticity of the wage curve and $\sigma_{\mathrm{L}}$ is the elasticity of substitution between formal and informal labor.

Table 4: Economic Impacts of Different Tax Reforms $\left(\sigma_{L}=5\right.$ and $\left.\theta=0.1\right)$

\begin{tabular}{|l|c|c|c|}
\hline & \multicolumn{3}{|c|}{ Alternative Tax Recycling } \\
\hline \multicolumn{1}{|c|}{$\%$ Changes } & Lump Sum T & Tax K & Tax L \\
\hline Welfare & -0.91 & -0.91 & 2.89 \\
\hline $\begin{array}{l}\text { Shadow Economy } \\
\text { (Base = 20\%) }\end{array}$ & 20.9 & 20.9 & 14.5 \\
\hline $\begin{array}{l}\text { Unemployment } \\
(\text { Base }=20 \%)\end{array}$ & 21.4 & 21.4 & 16.5 \\
\hline $\begin{array}{l}\text { CO2 Tax } \\
\text { US\$/tCO2 }\end{array}$ & 45.8 & 45.7 & 62.4 \\
\hline CO2 Emissions & -15.0 & -15.0 & -15.0 \\
\hline
\end{tabular}

D. We have also analysed the relative contributions of wage-unemployment flexibility and of movements between the formal and informal sectors. Taking the best guess values of the parameters for these functions we get, with a labour tax recycling scheme, a reduction in unemployment of $3.5 \%$. If there is no flexibility between formal and informal labour (the two are used in fixed proportions) the reductions in unemployment is smaller (3.2\%). So introducing an informal sector contributes about $0.3 \%$ to the estimated reduction in unemployment with the proposed tax shifts. On the other hand we also consider the case where we have flexibility between formal and informal labour in production but the unemployment-wage relationship is fixed so that a reduction in labour taxes is passed on to raise real wage by the full amount of the 
tax cut $(\theta \rightarrow \infty)$. In this case unemployment still falls a little (by 1.5\%), because workers from the informal sector are brought into the formal sector and this reduces the measured level of unemployment $^{13}$. We also note for each case, carbon taxes needed to achieve the $15 \%$ reduction in emissions are different. With full flexibility we need, as noted above, a tax of around US\$62/ton CO2. With only one of the dimensions of adjustment (either the wage-unemployment curve or the formal-informal labour markets) the tax is around US\$56/ton CO2. The main reason for this is that the $\mathrm{L}$ tax reform results in GDP growth, which raises emissions and requires a higher tax to achieve the $15 \%$ reduction target.

E. Finally we look at the reduction in local pollutants as a result of the tax reforms. These include $\mathrm{SO}_{2}$, NOx, Non-Metallic Volatile Organic Compounds, nitrous oxides, ammonia and particulate matter. Coefficients of emissions per unit of output by sector were taken from the National Statistical Office of Spain (INE 2009b) and valued in monetary terms using estimates for Spain made in the CASES Project (Markandya et al., 2010) ${ }^{14}$. In addition we valued the reductions in $\mathrm{CO} 2$, for which are range of estimates is available, with a lower bound of $€ 17.2 /$ tonne $\mathrm{CO} 2$-eq (\$21/tonne) and a higher bound of $€ 32 /$ tonne CO2-eq (US\$39/tonne) ${ }^{15}$. The CO2-eq estimates are taken from the EC (European Commission, 2008), the UK government (DECC, 2009) and a study conducted for the French government (Centre d'analyse stratégique, 2009). The results show a reduction in damages of the order of 1-2 billion euros (\$1.2-2.4 billion) with the labour tax recycling scheme. These reductions in total damages amount to between $0.3 \%$ (lower bound of $\mathrm{CO} 2-\mathrm{eq}$ ) and $1.1 \%$ (higher bound of $\mathrm{CO} 2-\mathrm{eq}$ ) of GDP and represent a significant addition to the EV welfare measures that were shown in Table 2. We also find that the reduction in damage is greater with the K and LST reforms than it is with the L tax reforms The reason for this is the greater reductions in emissions that one gets with the K and LST reforms, because of a bigger fall

\footnotetext{
13 Total unemployment, however, does not now fall as all that has happened is a shift of workers from the informal to the formal sector.

${ }^{14}$ Note all emissions that were quantified could be valued in monetary terms. In particular we could not value carbon monoxide $(\mathrm{CO})$ and methane due to lack of estimates. Furthermore estimates for damages from PM were limited to PM10 as no emissions data were available for PM2.5.

${ }^{15}$ Conversion to US dollars has been done at the average annual exchange rate prevailing in 2005, the year for which the impacts etc. have been estimated.
} 
in output in the K and LST reforms and possibly a shift to capital-intensive sectors that have lower emissions.

\section{Conclusions on the Double Dividend in Spain}

The analysis of the double dividend for Spain indicates that replacing part of the labor taxes with a carbon tax could have the benefit of some reduction in unemployment and either a small loss of welfare or a small gain (as measured by the equivalent variation (EV)). The EV measure, however, does not take account of the benefits of reduced emissions of local pollutants. Our latest analysis shows that if these are included the environmental tax reform results in a notable increase in welfare (around 2-3\%).

There is a question of the size of the fall in unemployment. The Manresa and Sancho study estimates a fall of around between 0.6 and $2.3 \%$. The Fæn et al. study focuses on differences between a reduction in the tax on skilled versus unskilled labor. Even if we take the more positive result (i.e. a recycling via reductions in skilled labor taxes), the fall is only about $0.3 \%$. Part of the difference may be due to very different environmental taxes regimes. Manresa et al really do not impose a carbon tax but rather a heavy tax on energy and petroleum products, which generates significant revenue. The Fæn et al. study on the other hand is strictly a carbon permit scheme. It also has much higher substitution possibilities between energy and capital, with the result that the carbon tax results in a bigger shift from energy to capital and less of a shift from energy to labor.

On the other hand our study, which is based on the 2005 input-output table, and which includes the informal labor market, estimates a gain of employment from an economy-wide carbon tax recycled via a reduction in labor taxes of around 3.5\%. We also allow for significant substitution possibilities between capital-labor and energy so we are not excluding the possibility of shifts to capital when energy becomes more expensive. 
Of course the model is highly stylized and takes no account of dynamic effects. Hence we could not expect a tax reform to generate the changes in one period, but rather to take place over a number of quarters. There is also the question of distributional effects that need to be assessed; while the increase in energy prices are countered by an increase in real wages for those who are employed there is no such countering effect for those who are not working, in particular pensioners, and those who still remain unemployed. Some measures to address possible fuel poverty impacts on these groups would need to be introduced. Finally there is the issue of competitiveness. The models used allow for the trade impacts of higher energy prices but they do not allow for capital mobility, which could cancel some of the effects if the carbon tax was passed on to capital. This effect will be significantly reduced of the reform is harmonized across trading partners, particularly member states of the EU.

In spite of all these qualifications, however, we would conclude that our analysis strengthens the case for an environmental tax reform in Spain involving recycling via a labor tax reduction. 


\section{References}

Arrazola M., Hevia J., Mauleón I. and Sánchez R. (2010), Estimación del volumen de economía sumergida en España. Cuadernos de Información Económica, 220, 81-88.

Babiker, M.H., Mayer M., Wieng I.S. y Hyman, R.C. (2001), The MIT emissions prediction and policy analysis (EPPA) model, MIT Global Change Joint Program, Working Paper 71.

Blanchflower D.G. and A.J. Oswald (1995), An introduction to the Wage Curve, Journal of Economic Perspectives, 9/3, 153-167

Blanchflower, D.G., Oswald, A.J. (2005) The wage curve reloaded. NBER Working Paper 11338. National Bureau of Economic Research, Cambridge MA.

Bosello, F., and C. Carraro (2001), Recycling energy taxes: impacts on a disaggregated labour market. Energy Economics, 23, 569-594.

Buehn A. and Schneider F. (2011), Shadow economies around the world: novel insights, accepted knowledge, and new estimates, International Tax and Public Finance, 1-33.

Cambridge Econometrics (1998), Industrial Benefits from Environmental Tax Reform in the UK, Cambridge Econometrics Technical Report no. 1, Sustainable Economy Unit of Forum for the Future.

Centre d'analyse stratégique (2009). Rapports et documents N.16/2009 - La valeur tutélaire du carbone Rapport de la commission présidée par Alain Quinet.

http://lesrapports.ladocumentationfrancaise.fr/BRP/094000195/0000.pdf

Department for Energy and Climate Change - DEEC (2009). Carbon Valuation in UK Policy Appraisal: A Revised Approach.

European Commission (2008). Commission Staff Working Document - Impact Assessment Document accompanying the Package of Implementation measures for the EU's objectives on climate change and renewable energy for 2020. SEC(2008) 85/3.

Eurostat (2005). Energy and environment statistics, European Statistic Office, www.eurostat.es.

Faehn, T., Gómez-Plana, A., S. Kverndokk (2009), Can a carbon permit system reduce Spanish unemployment? Energy Economics, 31, 4, 595-604

González-Eguino M., A. Markandya and M. Escapa (2012), "From Shadow to Green: Environmental Fiscal Reform and the informal economy", BC3 Working Paper, Bilbao.

González-Eguino, M, (2011), The importance of the design of Market-Based Instruments for CO2 mitigation: an AGE analysis for Spain, Ecological Economics, 70, 2292-2302

Harris J.R. and M. Todaro (1970) Migration, Unemployment and Development: A two sector Analysis, The American Economic Review, 60, 1, 126-142 
Heady. C, A. Markandya, W. Blyth, J. Collingwood and P.G. Taylor (2000), Study on the Relationship between Environmental/Energy Taxation and Employment Creation», Final Report, Prepared For The European Commission: Directorate General Xi Contract: B43040/98/00016/MAR/B1.

Hvidtfeldt, C., B. Jensen and C. Larsen (2011), Undeclared work and the Danes, University Press of Southern Denmark, English summary reported in: Rockwool Foundation Research Unit, Copenhagen, Denmark

INE (2009a). Contabilidad Nacional de España. Base 2000. Marco input-output. Tabla simétrica, Año 2005. Instituto Nacional de Estadística. www.ine.es.

INE (2009a). Cuentas satélite sobre emisiones atmosféricas. Año 2005. Instituto Nacional de Estadística. www.ine.es.

Labandeira, X., Linares, P. and Rodríguez, M. (2009), An Integrated Approach to Simulate the Economic Impacts of Carbon Emissions Trading, Energy Journal, 30, 2, 217-237.

Manresa, A. and F. Sancho (2005), Implementing a double dividend: recycling ecotaxes towards lower labour taxes, Energy Policy, 33, 1577-1585.

Markandya, A., A. Bigano and R. Porchia (eds.) (2010), The Social Costs of Electricity: Scenarios and Policy Implications, Edward Elgar Publishing.

Markandya. A. (2011), Environmental Taxation: What Have We Learnt in the Last 30 years? Rivista di Politica Economica, VII-IX, pp. 11-58.

Organization for Economic Cooperation and Development (1997), Environmental taxes and green tax reform, OECD, Paris.

Pearce D. (1991), The role of carbon taxes in adjusting to global warming, Economic Journal, 101, 938-948.

Rutherford T. and M. Light (2002), A General Equilibrium Model for Tax Policy Analysis in Colombia: The MEGATAX Model, Working paper.

Schneider F. (2011), The Shadow Economy and Shadow Economy Labor Force: What Do We (Not) Know? IZA Discussion Paper No. 5769. Forthcoming in World Economics 2012.

Schneider F. and D. Enste (2000), Shadow Economies: Size, Causes and Consequences, Journal of Economic Literature, 38, 77-114 


\section{BC3 WORKING PAPER SERIES}

\section{Basque Centre for Climate Change (BC3), Bilbao, Spain}

The BC3 Working Paper Series is available on the internet at the following addresses:

http://www.bc3research.org/lits_publications.html

$\underline{\text { http://ideas.repec.org/s/bcc/wpaper.html }}$

BC3 Working Papers available:

2011-05 Wan-Jung Chou, Andrea Bigano, Alistair Hunt, Stephane La Branche, Anil Markandya, Roberta Pierfederici: Households' WTP for the Reliability of Gas Supply

2011-06 Roger Fouquet and Peter J.G. Pearson: The Long Run Demand for Lighting: Elasticities and Rebound Effects in Different Phases of Economic Development

2011-07 Ibon Galarraga, David Heres Del Valle and Mikel González-Eguino: Price Premium for High-Efficiency Refrigerators and Calculation of Price-Elasticities for Close-Substitutes: Combining Hedonic Pricing and Demand Systems

2011-08 Anil Markandya, Mikel González-Eguino, Patrick Criqui, Silvana Mima: Low Climate Stabilisation under Diverse Growth and Convergence Scenarios

2011-09 Martin Altemeyer-Bartscher, Anil Markandya and Dirk Rübbelke: The Private Provision of International Impure Public Goods: the Case of Climate Policy

2011-10 Aline Chiabai, Ibon Galarraga, Anil Markandya and Unai Pascual: The Equivalency Principle for Discounting the Value of Natural Assets: An Application to an Investment Project in the Basque Coast

2011-11 Roger Fouquet: The Demand for Environmental Quality in Driving Transitions to Low Polluting Energy Sources

2011-12 Joseph V. Spadaro: The Uniform World Model: A Methodology for Predicting the Health Impacts of Air Pollution

2011-13 Thomas Heyd: Climate Change, Responsibilities, and Defeatism and Complacency

2012-01 Roger Fouquet: Trends in Income and Price Elasticities of Transport Demand (18502010)

2012-02 Sébastien Foudi: Exploitation of soil biota ecosystem services in agriculture: $a$ bioeconomic approach

2012-03 Mikel González-Eguino, Anil Markandya and Marta Escapa: From shadow to green: Linking environmental fiscal reform and the informal economy

2012-04 Anil Markandya, Mikel González-Eguino and Marta Escapa: Environmental fiscal reform and unemployment in Spain 